\title{
Chikungunya in Jamaica - Public Health Effects and Clinical Features in Children
}

\author{
CDC Christie ${ }^{1}$, R Melbourne-Chambers ${ }^{1}$, J Ennevor ${ }^{2}$, S Young-Peart ${ }^{2}$, T Buchanan ${ }^{2}$, P Scott-Brown ${ }^{2}$, N McNeil-Beecher $^{2}$,
} T Fulford-Ramdial ${ }^{2}$, M Richards-Dawson ${ }^{2}$, T James-Powell ${ }^{3}$, ST Jackson ${ }^{4}$

\begin{abstract}
Background: Chikungunya virus (CHIKV) entered the Caribbean for the first time in 2013 and Jamaica experienced its maiden epidemic with Chikungunya Fever in 2014. We aimed to describe the public health effects and describe the clinical features in children and adolescents in Jamaica.

Methods: This study reviewed the public health effects of the illness in Jamaica by reviewing available data sources and the clinical features in 210 children and adolescents meeting the case definition at two hospitals, Bustamante Hospital for Children and University Hospital of the West Indies between August 23 and October 31, 2014 by chart review. Descriptive analyses and comparisons between groups using the Mann-Whitney U test were performed with SPSS version 22.

Results: The majority of households were affected by the illness which caused widespread absenteeism from school and work, loss of productivity and economic losses estimated at 60 billion dollars. The health sector was impacted by increased numbers seen in clinics and emergency departments, increased need for bed space and pharmaceuticals. Ninety-nine per cent of the children were febrile with a median maximal temperature of $102.4 \mathrm{~F}$. Ninety-three per cent had household contacts of 0-20 persons. In addition to fever, maculopapular rash and joint pains, infants six months and younger presented with irritability and groaning $(\mathrm{p}=0.00)$ and those between six months and six years presented with febrile seizures $(\mathrm{p}=$ 0.00). Neurologic involvement was noted in $24 \%$. Apart from anaemia, few had other laboratory derangements. Few had severe organ dysfunction and there were no deaths.

Conclusion: The Chikungunya Fever epidemic had significant public health and economic impact in Jamaica. In children, there were characteristic presentations in neonates and young infants and in children six months to six years. Neurologic involvement was common but other organ dysfunction was rare. These findings underscore the need to prevent further epidemics and the quest for a vaccine.
\end{abstract}

Keywords: Aedes aegypti, Chikungunya, children, clinical features, Dengue, epidemic, Jamaica, Zika virus

\section{Chikungunya en Jamaica - Efectos en la Salud Pública y Características Clínicas en Niños}

CDC Christie ${ }^{1}$, R Melbourne-Chambers ${ }^{1}, \mathrm{~J}_{\text {Ennevor }}^{2}$, S Young-Peart ${ }^{2}, \mathrm{~T}$ Buchanan ${ }^{2}, \mathrm{P}_{\text {Scott-Brown }}^{2}$, N McNeil-Beecher ${ }^{2}$, T Fulford-Ramdial ${ }^{2}$, M Richards-Dawson ${ }^{2}$, T James-Powell ${ }^{3}$, ST Jackson ${ }^{4}$

\section{RESUMEN}

\begin{abstract}
Antecedentes: El virus de Chikungunya (CHIKV) entró en el Caribe por primera vez en 2013, y Jamaica experimentó su primera epidemia de fiebre de Chikungunya en 2014. Nos propusimos como objetivo describir sus efectos en la salud pública y describir sus características clínicas en niños y adolescentes en Jamaica.

Métodos: Este estudio examinó los efectos de la enfermedad en la salud pública en Jamaica. El examen se realizó mediante la revisión de fuentes de datos disponibles y las características clínicas en 210 niños y adolescentes que cumplían con la definición del caso en dos hospitales - Hospital Pediátrico Bustamante y el Hospital Universitario de West Indies - entre el 23 de agosto y 31 de octubre de 201, según
\end{abstract}

From: ${ }^{1}$ Departments of Paediatrics (Child) and Adolescent Medicine, ${ }^{2}$ The University of the West Indies, Kingston 7, Jamaica, Bustamante Hospital for Children, Kingston, Jamaica, ${ }^{3}$ Spanish Town Hospital, St Catherine, Jamaica, and ${ }^{4}$ Department of Microbiology, Section of Virology, The University of the West Indies, Kingston 7, Jamaica.
Correspondence: Professor CDC Christie, Department of Child and Adolescent Health. The University of the West Indies, Mona Campus, Kingston 7, Jamaica. Email: Celia.ChristieSamuels@uwimona.edu.jm 
las historias clínicas. Se realizaron análisis descriptivos y comparaciones entre los grupos usando la prueba U de Mann-Whitney y la versión 22 de SPSS

Resultados: La mayoría de los hogares fueron afectados por la enfermedad, que causó un ausentismo generalizado en escuelas y trabajos, pérdida de productividad, y pérdidas económicas estimadas en 60 billones de dólares. El sector de la salud fue afectado por un aumento del número de personas atendidas en clínicas y departamentos de urgencias, y una mayor necesidad de camas en los hospitales y productos farmacéuticos. Noventa y nueve por ciento de los niños presentaron un estado febril con una temperatura mediana máxima de $102.4 \mathrm{~F}$. Un noventa y tres por ciento tuvo contactos domésticos de personas de 0-20. Además de fiebre, erupciones maculopapulares y dolores en las articulaciones, los niños de seis meses o menos edad, presentaron irritabilidad y quejidos $(\mathrm{p}=0.00)$, y aquellos entre seis meses $y$ seis años de edad presentaron convulsiones febriles $(\mathrm{p}=0.00)$. Se observó compromiso neurológico en el 24\%. Aparte de anemia, algunos tenían otros trastornos de laboratorio. Otros presentaban una disfunción orgánica severa y no hubo muertes.

Conclusión: La epidemia de fiebre de Chikungunya tuvo un impacto significativo tanto en la salud pública como en la economía de Jamaica. Los niños presentaron manifestaciones características, observadas tanto en recién nacidos y bebés pequeños como en niños de seis meses a seis años. El compromiso neurológico fue común, pero cualquiera otra disfunción orgánica fue rara. Estos hallazgos subrayan la necesidad de hacer más por evitar las epidemias y buscar la solución de una vacuna.

Palabras claves: Aedes aegypti, Chikungunya, niños, características clínicas, dengue, epidemia, Jamaica, virus del Zika

West Indian Med J 2016; 65 (3): 432

\section{INTRODUCTION}

In Jamaica, the Aedes aegypti mosquito has caused recent major disease epidemics of dengue fever in 2012, ZIKA fever 2016 and Chikungunya (CHIKV) fever in 2014. Chikungunya virus (CHIKV) is an arbovirus which causes an acute febrile illness with severe joint pains and means "being bent up" in the Makonde African dialect. The first outbreak of CHIKV fever occurred in southern Tanzania in 1952. The Caribbean experienced its first outbreak of CHIKV in 2013 - 2014. The first cases were identified in St Maarten on December 6, 2013 (1) and by October 31, 2014 (2) there were, approximately 750 000 suspected cases in 37 countries. There are three CHIKV genotypes, the East-Central-South African, West African and Asian genotypes; the Asian genotype was responsible for the 2014 outbreak in the Caribbean (3). This study was undertaken to document the public health impact of Chikungunya Fever (CHIKV) in Jamaica and the clinical effects in Jamaican children.

\section{Public health effects of CHIKV in Jamaica}

Jamaica, a middle developing island Caribbean nation with a population of 2.8 million, identified its first imported, travelrelated cases of CHIKV on July 17 and 27, 2014 (4). The first case of local transmission by the vector Aedes aegypti in Jamaica was reported on August 5, 2014 (4). The disease was first reported in the eastern parishes of St Thomas, Kingston and St Andrew but rapidly spread westward across the island with the peak number of suspected cases reported in epidemiology week 38 of 2014 (5). At the end of 2014, 1370 suspected cases and 87 confirmed cases were reported by Pan American Health Organization [PAHO] (6).
A review of available data sources in the media and on public health websites was undertaken to describe the public health effects of CHIKV in Jamaica. Eighty-seven per cent of Jamaican families reported having household members affected by CHIKV with 50\% reporting four or more household members being affected and one-third being severely affected by CHIKV (7). The number of emergency room visits for children at the two public hospitals, Bustamante Hospital for Children (BHC) and University Hospital of the West Indies (UHWI) in the capital region, Kingston and St Andrew, increased by as much as five-fold during epidemiology weeks 37-40 of 2014 when compared with the similar period in 2013 (Fig. 1). This strained human resources, laboratory resources

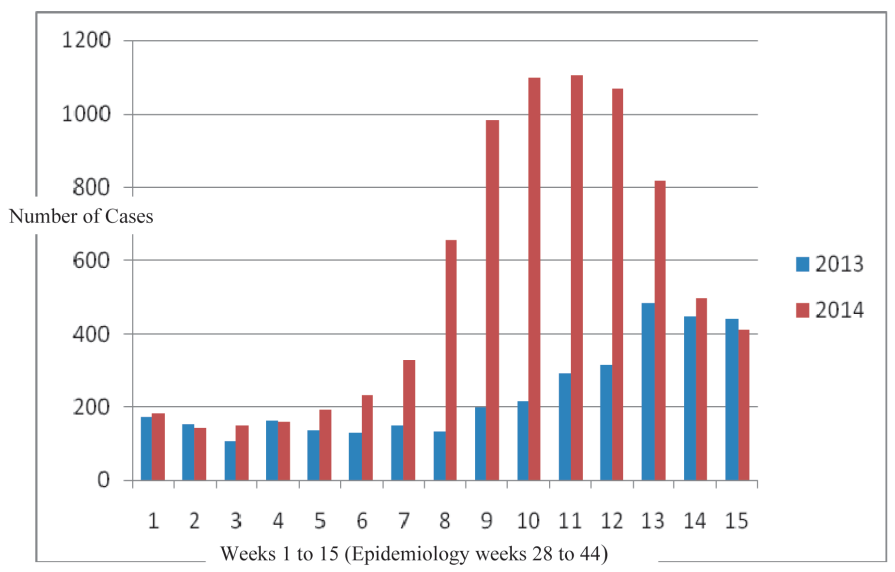

Fig. 1: Epidemic curves of children presenting to Emergency Rooms of Bustamante Hospital for Children with fever, during each week for the period September to October, 2013 vs September to October, 2014 (Epidemiology weeks 28 to 44 ). 
and pharmaceutical supplies and resulted in the need for additional bed space $(8,9)$. The Jamaican Military had to erect a field hospital at the $\mathrm{BHC}$ to provide added bed space. There was also increased absenteeism of students and staff from schools resulting in school closure $(10,11)$. Three attributable deaths, of two students and one teacher from one school were reported in the media $(12,13)$.

The economy was also significantly impacted by the outbreak. There was widespread absenteeism in the labour force. The Private Sector Organisation of Jamaica reported that up to $60 \%$ of the work force was affected and estimated that 13 million man-hours and six billion dollars in revenue were lost (14). An epidemic was formally declared by the Prime Minister to mobilise resources. This resulted in the activation of a National Emergency Response Team in Jamaica to coordinate and support the country's response which included clean-up of the environment, vector control and public education campaigns and a response from the CARICOM Heads of Government on November 4, $2014(15,16)$.

\section{Clinical features in Jamaican children and adolescents}

During the community-wide CHIKV epidemic and for the purpose of this clinico-epidemiologic study, the modified chikungunya case definition, specific for children hospitalized at two of 14 in-hospital paediatric sites (BHC and UHWI) during August 23, to October 31, 2014, was used. This included fever, with or without skin rash and joint pain, or swelling, epidemiologically linked to chikungunya (fever, joint pains, rash) within their household, or those having a positive CHIKV laboratory test (PCR, or IgM ELISA), or physician-diagnosed chikungunya. The records of all paediatric cases meeting the case definition at UHWI whose clinical records were available and a subset, $10 \%$ of children admitted to $\mathrm{BHC}$ were reviewed. Data on demography, clinical features, laboratory results and mortality were extracted and entered into SPSS version 22. Descriptive analyses were performed and comparisons between groups using the Mann Whitney $\mathrm{U}$ test. A $p$-value of 0.05 or less was significant.

\section{Demography}

During the study period, there was a record increase in visits to the emergency rooms of both hospitals (Figs. 1 and 2), with as high as a $500 \%$ increase compared to the previous year and as many as 1100 visits per week to the emergency department of Bustamante Hospital for Children (Fig. 1). Two hundred and ten hospital charts were reviewed. The median (min, max) age of the children was $0.2(0,17.7)$ years and $60 \%$ were male (Table 1). Household exposures to CHIKV, involving up to 20 persons, were reported for $189(92.6 \%)$. Two hundred and seven $(98.6 \%)$ were febrile with a median ( $\min$, max) temperature of $102.4(98.8,105.0){ }^{\circ} \mathrm{C}$. Fever was short-lived across all age groups mean (sd) duration of 2.8 (1.3) days. There were no reports of Non-Steroidal Anti-inflammatory drug (NSAID) use. The median duration of hospitalization was 3.0 days

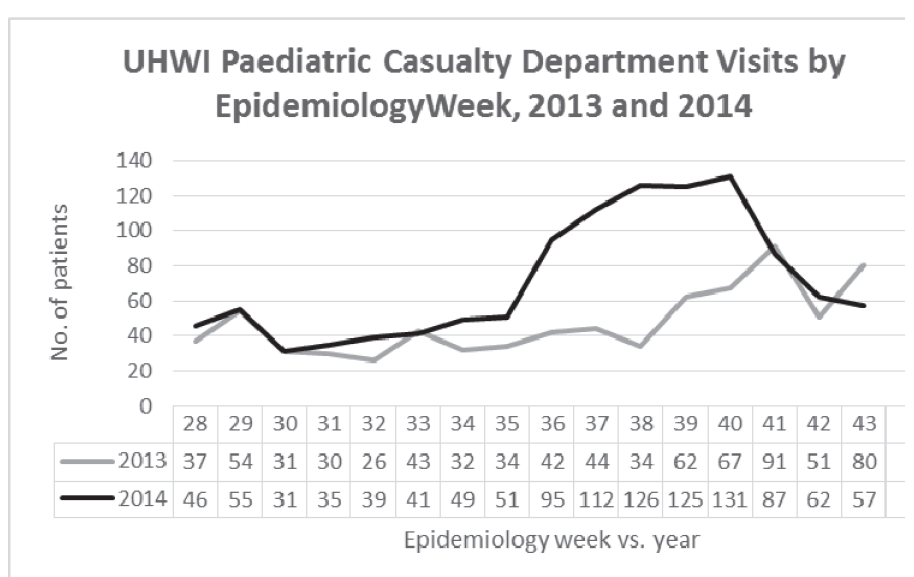

Fig. 2: Epidemic curves of children presenting to the Emergency Rooms of the University Hospital of the West Indies (UHWI), Kingston, Jamaica during September to October, 2013 vs September to October, 2014.

(Table 2). Few had co-morbid illnesses. There were no deaths. Laboratory testing for CHIK V was performed in 14 (6.7\%). Seven (70\%) samples processed for immunoglobulin M (IgM) to $\mathrm{CHIKV}$ and two $(100 \%)$ processed for CHIKV polymerase chain reaction (PCR) were positive.

\section{Clinical issues highlighted variable presentations in three age groups}

Newborns and neonates: They were disproportionately affected and along with others aged less than six months, were most likely to be hospitalized. They presented primarily with sudden onset of high fever with rash, loud groaning and crying on involuntary (eg startle), or voluntary movement, presumably because of severe joint pains. Groaning and irritability were the significantly most likely presentations in this age group $(p=0.00)$. Rash was also significantly represented in this age group $(p=0.02)$. A rash, which began as an erythematous "red flush" of the palms and soles, then spread to the face, limbs and trunk and quickly became maculopapular followed by desquamation within three to five days, or more (after discharge from hospital) was the most common manifestation (Table 2, Fig. 3) Other rashes documented in this age group included vesicular, bullous and erythematous rashes noted in $3(2.2 \%), 1(0.7 \%)$ and $1(0.7 \%)$, respectively. Thirteen $(9.6 \%)$ were diagnosed with an aseptic meningitis.

Perinatal infection with CHIK $V$ : Twenty-one (10.3\%) presented at age 0 to 14 days reflecting possible mother-tochild blood-borne transmission (Table 2, Figure 3). Thirteen $(62 \%)$ were female. These neonates presented with fever (100\%), irritability (71\%), groaning (67\%) and maculopapular rash $(57 \%)$. The temperature on admission ranged from 100.9 ${ }^{0} \mathrm{C}$ to $104.1{ }^{\circ} \mathrm{C}$. One $(4.8 \%)$ each had diarrhoea, myocarditis and conjunctivitis. No neonate had seizures. One had anaemia and three had lymphopaenia. None was thrombocytopaenic, or had CSF pleocytosis. Two (9.5\%) were PCR positive for 
Table 1: Chikungunya in children at the BHC and UHWI, Kingston, Jamaica - demography

\begin{tabular}{|c|c|c|c|c|}
\hline Characteristic & $\begin{array}{l}\text { Age, } N(\%) \\
0 \text { to } \leq 6 \text { months } \\
136(67 \%)\end{array}$ & $\begin{array}{l}6.1 \text { months to } \\
6 \text { years } 46(21 \%)\end{array}$ & $\begin{array}{l}6.1 \text { to } 18 \text { years } \\
28(12 \%)\end{array}$ & $\begin{array}{l}\text { Total }=210 \\
\text { BHC }=138 \\
\text { UHWI }=72\end{array}$ \\
\hline Median age (yrs), (range) & $0.1(0,0.4)$ & $1.8(0.6,5.5)$ & $10.2(6.2,17.7))$ & $0.2(0,17.7)$ \\
\hline Males $(\%)$ & $74(54.8)$ & $30(66.7)$ & $20(71.4)$ & $124(59.0)$ \\
\hline $\begin{array}{l}\text { Chikungunya fever like illness in } \\
\text { household, } \mathrm{n}(\%)\end{array}$ & $131(96.3)$ & $41(9.1)$ & $19(67.9)$ & $191(91.0)$ \\
\hline $\begin{array}{l}\text { Median number of household contacts } \\
\text { (range) }\end{array}$ & $2(1,20)$ & $2(0,7)$ & $1(0,3)$ & $2(0,20)$ \\
\hline \multicolumn{5}{|l|}{ Predisposing } \\
\hline \multicolumn{5}{|l|}{ Conditions, $\mathrm{n}(\%)$, viz: } \\
\hline Newborns & $42(30.9)$ & $0(0)$ & $0(0)$ & $42(20.0)$ \\
\hline Perinatal infection ( $0-14$ days) & $22(16.3)$ & $0(0)$ & $0(0)$ & $22(10.5)$ \\
\hline Malnutrition & $1(0.7)$ & $0(0)$ & $0(0)$ & $1(0.5)$ \\
\hline End-stage renal disease & $0(0)$ & $0(0)$ & $1(3.6)$ & $1(0.5)$ \\
\hline Acute lymphoblast leukaemia & $0(0)$ & $0(0)$ & $1(3.6)$ & $1(0.5)$ \\
\hline Sickle cell disease & $0(0)$ & $3(6.7)$ & $2(7.1)$ & $5(2.4)$ \\
\hline HIV & $0(0)$ & $0(0)$ & $2(7.1)$ & $2(1.0)$ \\
\hline Diabetes mellitus & $0(0)$ & $0(0)$ & $1(3.6)$ & $1(0.5)$ \\
\hline Epilepsy & $0(0)$ & $2(4.4)$ & $0(0)$ & $2(1.0)$ \\
\hline
\end{tabular}

Table 2: Chikungunya in children at the BHC and UHWI, Kingston, Jamaica-clinical and laboratory characteristics

\begin{tabular}{|c|c|c|c|c|}
\hline Characteristic & $\begin{array}{c}\text { Age, } N(\%) \\
0 \text { to } \leq 6 \text { months } \\
136(67 \%)\end{array}$ & $\begin{array}{c}6.1 \text { months to } 6 \text { years } \\
46(21 \%)\end{array}$ & $\begin{array}{l}6.1 \text { to } 18 \text { years } \\
28(12 \%)\end{array}$ & $\begin{array}{l}\text { Total }=\mathbf{2 1 0} \\
\text { BHC }=138 \\
\text { UHWI }=72\end{array}$ \\
\hline Fever, n (\%) & $135(99.3)$ & $46(100)$ & $26(92.1)$ & 207 (98.6) \\
\hline Tmax (F), median (range) & $102.2(98.8,104.9)$ & $102.5(101.2,104.9)$ & $103(99,105)$ & $102.4(98.8,105)$ \\
\hline Fever duration, mean (s.d.) & $2.8(0.99)$ & $2.8(2.1)$ & $3.1(1.3)$ & $2.8(1.3)$ \\
\hline Length of hospitalisation (d), median (range) & $4(0,18)$ & $3(0,11)$ & $2(0,10))$ & $3(0,18)$ \\
\hline \multicolumn{5}{|l|}{ Other Disease manifestations, $\mathrm{n}(\%)$} \\
\hline Irritability* & $115(84.5)$ & $20(43.5)$ & $0(0.0)$ & $135(64.3)$ \\
\hline Groaning* & $115(84.5)$ & $17(36.9)$ & $2(7.1)$ & $133(63.3)$ \\
\hline Rash & $95(70.4)$ & $16(35.6)$ & $11(39.3)$ & $122(58.1)$ \\
\hline Maculopapular rash on an erythematous base & $87(64.4)$ & $14(31.1)$ & $8(28.6)$ & $109(51.9)$ \\
\hline Joint pain* & $18(13.3)$ & $20(44.4)$ & $21(75)$ & $59(28.1)$ \\
\hline Large & $6(4.4)$ & $10(22.2)$ & $9(32.1)$ & $25(11.9)$ \\
\hline Small & $3(2.2)$ & $1(2.2)$ & $1(3.6)$ & $5(2.4)$ \\
\hline Large and small & $7(5.2)$ & $8(17.8)$ & $11(39.3)$ & $26(12.4)$ \\
\hline Seizures with fever* & $1(0.7)$ & $30(65.2)$ & $6(21.4)$ & $37(17.6)$ \\
\hline Muscle pain & $13(9.6)$ & $13(28.9)$ & $8(28.6)$ & $34(16.2)$ \\
\hline Vomiting & $13(9.6)$ & $10(21.7)$ & $8(28.6)$ & $31(14.8)$ \\
\hline Joint swelling & $6(4.4)$ & $7(15.6)$ & $4(14.3)$ & $17(8.1)$ \\
\hline Diarrhoea & $10(7.4)$ & $1(2.2)$ & $2(7.1)$ & $13(6.2)$ \\
\hline Headache & $0(0)$ & $1(2.2)$ & $14(50)$ & $15(7.1)$ \\
\hline Eye pain & $0(0)$ & $0(0)$ & $5(17.9)$ & $5(2.4)$ \\
\hline \multicolumn{5}{|l|}{ Laboratory abnormalities } \\
\hline Leucopenia & $7(5.2)$ & $3(6.7)$ & $3(10.7)$ & $13(6.2)$ \\
\hline CSF pleocytosis & $13(9.6)$ & $5(11.1)$ & $0(0.0)$ & $18(8.9)$ \\
\hline Elevated liver enzymes & $1(0.7)^{b}$ & $0(0.0)$ & $0(0.0)$ & $1(0.5)$ \\
\hline Elevated creatinine & $1(0.7)^{\mathrm{b}}$ & $0(0.0)^{\mathrm{c}}$ & $2(7.1)^{\mathrm{c}}$ & $3(1.4)$ \\
\hline
\end{tabular}

*Mann Whitney $\mathrm{U}$ test, significant difference in the mean rank of the ages for the presence of the symptom $(p=0.00)$

${ }^{\text {a }}$ Includes three with HbSS disease

${ }^{\mathrm{b}} \mathrm{A}$ 32-day old female with multiorgan dysfunction, anaemia, leucopenia and CSF pleocytosis

${ }^{\mathrm{A}} \mathrm{A} 7$-year old male with End stage renal disease and an 11-year old female with nephritis 


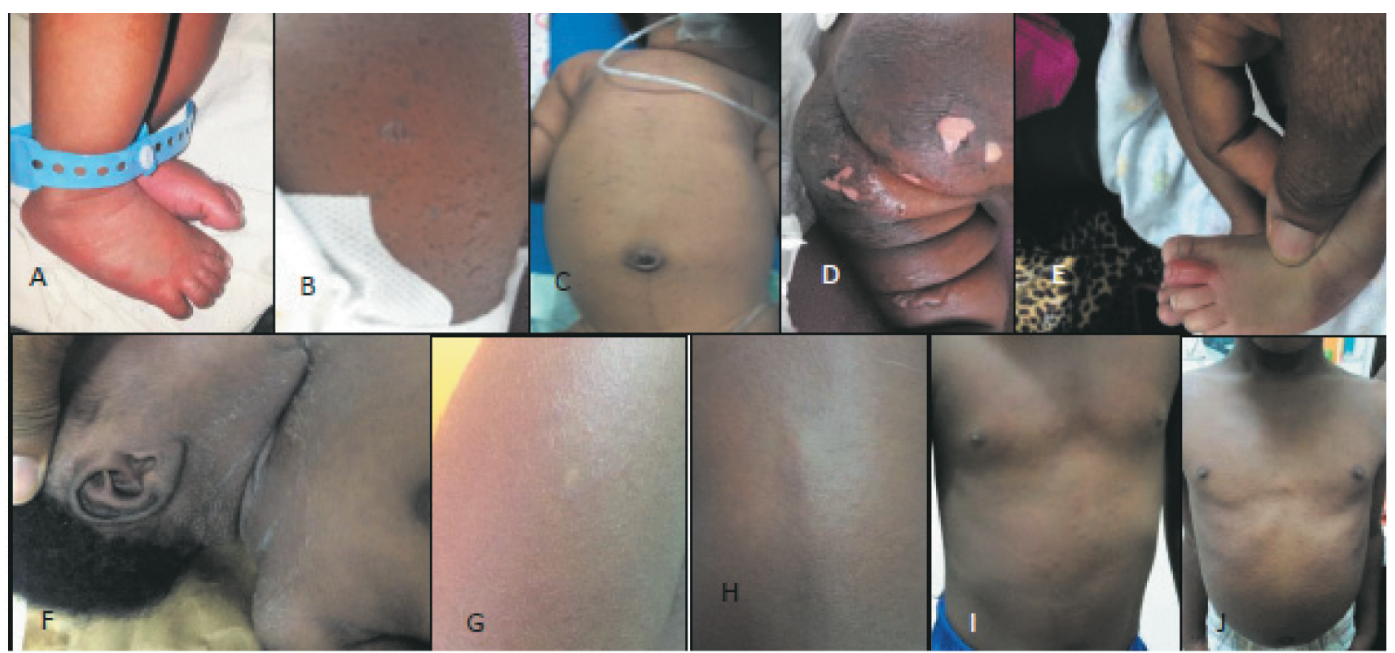

Fig. 3: Skin and joint manifestations of Chikungunya in Jamaican children

\begin{abstract}
Erythematous patches of the dorsum of the foot and distal lower limb and oedema of the joints of the left great toe - infant (A), Numerous vesicular lesions (early phase) and macular hyperpigmented lesions (late phase) of the abdominal wall - infant (B), Hyperpigmented macules on the abdomen - infant (C), Bullous lesions of the extensor surface of the lower limbs and denudation and hyperpigmentation of the diaper area - infant (D), Arthritis, left second toe, infant (E), Desquamation of the skin, infant (F), Erythematous papular rash with desquamation of the shoulder - older child $(G)$, Erythematous papular rash $(H)$, Urticarial rash of the chest and abdomen - older child (I), Erythematous maculopapular rash of the chest and abdomen - older child (J).
\end{abstract}

CHIKV; one was less than 24 hours old and the other was 13 days old. The mean (sd) duration of fever was 2.9 (2.8) days. The mean (sd) length of hospitalization was 5.8 (3.8) days.

Children aged six months to six years: These children presented with high fever heralded by febrile convulsions, whether simple - managed as an outpatient, or complex - warranting hospitalization (Table 2). Seizures with fever was the significantly most likely presentation in this age group $(p=$ 0.00 ). This was accompanied by a maculopapular generalised rash as well as groaning and irritability from severe arthralgia $(41 \%)$ and arthritis (16\%) primarily involving the large joints, with reluctance to weight-bear, or walk. A lumbar puncture was performed for $20(66.7 \%)$ with seizure with fever; five $(25 \%)$ had cerebrospinal fluid pleocytosis.

Children older than six years of age: These children presented with high fever, headache, joint pains and maculopapular rash (Fig. 3, Table 2). Joint pains were significantly more likely to be articulated as a presentation in this age group $(p=0.00)$.

\section{Dermatological manifestations}

The most commonly described rash was a maculopapular rash on an erythematous base in 107 [52\%] (Table 2, Fig. 3). This was most commonly seen in infants younger than six months. Other rashes included urticaria, bullae, or tiny vesicles which morphed into macular hyperpigmented pin-point lesions.

\section{Neurological manifestations}

Apart from fever, rash and arthralgia, the other common presentation was neurological with headache and/or seizures (Table $2)$. Forty-nine $(24.1 \%)$ persons presented with neurologic symptoms or signs. Neurologic manifestations were more common in children older than six months old. Headache was significantly more common in the age group older than six years $(12(24.4 \%) p=0.00)$. Seizures were most common amongst those age six months to six years $(30(61.2 \%) p=$ $0.00)$. There was one child with Guillain Barre syndrome and another with altered sensorium, but with no CSF pleocytosis who were older than six years.

\section{Laboratory abnormalities}

The most common laboratory abnormalities were cerebrospinal fluid pleocytosis and anaemia (Table 2). None had thrombocytopaenia. One child had hepatitis and another had nephritis associated with the illness.

\section{DISCUSSION}

The chikungunya fever epidemic in Jamaica in 2014 affected the majority of Jamaicans and resulted in significant absenteeism from work and school, marked economic losses, excessive demand on the health system, significant morbidity and also deaths. The economic effects of CHIKV during the 20062007 epidemic have been reported from India in terms of out of pocket expenses, disability adjusted life years and loss of productivity with an estimated median of 35 days lost from work (17-19). For our study, there was no data published on the effect of the chronic symptoms of CHIK V on productivity and disability and therefore the impact of the acute infection is likely be an underestimate of the total effect of the disease. These data are significant indicators of the effect of the illness particularly in naïve populations. 
This study also revealed that there was apparent underreporting of cases. Although $90 \%$ of Jamaicans interviewed reported that their household members were affected by CHIKV, the official numbers suspected and confirmed were much less. As the epidemic progressed, most persons may not have sought medical attention and increased active case surveillance directly from the public, may have increased reporting of cases meeting the case definition.

Children with chikungunya fever presenting to the University Hospital of the West Indies and Bustamante Hospital for Children during the height of community-wide epidemic experienced high fevers, headache, joint pain, skin rash and seizures with fever. Although very few had laboratory tests processed for CHIKV PCR or IgM antibodies to CHIKV, the sensitivity of both tests was reasonably high and is comparable with other studies of CHIKV in children $(20,21)$.

Two distinct syndromes were recognized. In infancy, the presentation was of fever, groaning, irritability and skin rash. In the older infant - school age child - the presentation was with fever, arthralgia, skin rash, vomiting and seizures with fever. Groaning and irritability in the infant was a highly characteristic presentation and may have been due to both arthralgia and headache. Similar patterns of presentation have been noted in an epidemic of chikungunya fever in Kerala, India, reported in 2009 (22) except that circulatory failure was a common complication in infants younger than six months in Kerala and was rare in our study population. In the present study, cases with presumed mother-to-child transmission presented similar to the other young infants with fever, groaning, irritability and skin rash.

Compared with the series of neonates in Reunion described by Ramful et al (23), in which the majority of neonates had thrombocytopaenia and deranged coagulation and seizures and haemorrhagic syndromes and haemodynamic disorders were noted in $10-30 \%$, neonates in our study presumed to have mother-to-child transmission of the illness had a milder course as none had seizures and only one had myocarditis. No neonate in our study required ventilatory support. Teo et al have shown that the strain of the chikungunya virus responsible for the outbreak in the Caribbean and the Americas in the epidemic which started in October 2013 is the Asian genotype (24). This Asian strain induces weaker pro-inflammatory effects than the Indian Ocean genotype responsible for outbreaks in La Reunion.

Apart from arthralgia and skin rash, the most prominent presentation was with neurological signs of headache and seizures with fever; there was one case each of ascending paralysis and personality change. Myeloradiculopathy, optic neuropathy and sensorineural deafness have all been described as neurological sequelae to infection with CHIKV (25-29). Elenjickal and Sushamabai reported that $80 \%$ of children between six months and five years old hospitalized in Kerala, India, and presumed to have Chikungunya fever had febrile seizures (22). Robin et al reported much fewer cases of seizures in children with CHIK V from La Reunion in 2009
(29). Van Genderen in a study of CHIKV in Suriname with few children ages two to 12 years documented no seizures (30). The difference in the neurologic presentations among the populations may reflect a different strain of the virus. Wei-Chiam has noted that the Asian genotype has greater neurovirulence than the East/Central/South African genotype in mice and this was due to upregulaton of pro-aptotic genes and less upregulation of genes involved in anti-apoptosis, antiviral and central nervous system protective responses (31).

\section{Strengths and limitations}

This report describes the public health effects of Chikungunya fever in Jamaica and characterises the clinical presentation in children during the outbreak in the Caribbean in 2014. Follow-up clinical data was not captured and therefore data on the chronic complications experienced by the population and the attributed economic impact were not available for this report. The absence of supporting laboratory confirmation for the majority of cases was a limitation and reflects the deficits in laboratory resources at the time of the outbreak.

\section{CONCLUSION}

Jamaica continues to experience epidemics of arboviral diseases, including dengue and ZIKA fevers which are also caused by the Aedes aegypti mosquito $(32,33)$. The maiden epidemic of CHIKV in Jamaica had significant public health and economic impact. There was under-reporting of cases and laboratory resources to investigate the epidemic were limited. Children were significantly affected. Apart from fever, rash and arthralgia, seizures with fever was a common hospital presentation. Other manifestations of severe illness, eg thrombocytopaenia and circulatory failure were rare. Following this epidemic, it is anticipated that there will be recurrent outbreaks in non-immune populations within Jamaica as the vector persists. In addition to early recognition and reporting of CHIKV cases as well as implementing needed public health interventions, prospects for an effective vaccine, must be aggressively explored for susceptible populations $(34,35)$. As natural immunity will likely confer lifelong protection, CHIKV experienced populations may benefit from infant immunization after maternally-derived natural transplacental immunity has waned, beginning at about $12-15$ months and again at $4-6$ years.

\section{ACKNOWLEDGMENTS}

We thank Dr Kevin Harvey, Ministry of Health, Jamaica and the staff of the University Hospital of the West Indies and Bustamante Hospital for Children for their assistance in implementing this project.

\section{REFERENCES}

1. Cassadou S, Boucau S, Petit-Sinturel M, Huc P, Leparc-Goffart I, Ledrans M. Emergence of chikungunya fever on the French side of Saint Martin island, October to December 2013. Euro Surveill 2014; 19: (pii.20752).

2. Centers for Disease Control and Prevention. Chikungunya in the Americas. [Accessed 12 Nov, 2014]. Available from; http://www.cdc.gov/ chikungunya/geo/americas.html. 
3. Leparc-Goffart I, Nougairede A, Cassadou S, Prat C, de Lamballerie X. Chikungunya in the Americas. Lancet 2014; 383: 514.

4. Linton L. "Two New Cases of Chikungunya". Jamaica Information Service. 2014 Aug 8: News.

5. Chikungunya: PAHO/WHO Data, Maps and Statistic 2014. http:// www.paho.org/hq/index.php?option=com_topics\&view=rdmore\&cid=79 28\&Itemid $=40931 \&$ lang=en

6. RJR. Jamaica Observer. Nine out of 10 families affected by Chikungunya - Don Anderson poll. 2014 Dec 14: News.

7. Jamaica Observer. Bustamante Hospital seeing only 'critical' cases. Jamaica Observer. 2014 Oct 1: News.

8. Jamaica Observer. FFP to donate paracetamol to fight Chik-V. Jamaica Observer. 2014 Oct 9: News.

9. Matthews K. Mass illness hits St Thomas schools: students, teachers forced to stay home with flu-like symptoms, joint pains and rashes. Jamaica Observer. 2014 Sep 16: News.

10. Jamaica Gleaner. Schools coping with Chikungunya outbreak. Jamaica Gleaner. 2014 Oct 8: News.

11. Jamaica Observer. Vere Tech mourns CHIKV-related death of teachers, student. Jamaica Observer. 2014 Oct 17: News.

12. Jamaica Observer. 10-year old dies from CHIKV complications. Jamaica Observer. 2014 Oct 17: News.

13. Collinder A. Chik-V seen as costing billions in lost productivity. Jamaica Gleaner. 2014 Oct 15: News.

14. PM's Statement Regarding National Response to CHIKV Outbreak. OPM Communications Unit. 2014 Oct 9: News.

15. Jamaica Observer. Caricom adopts 10-point plan to deal with CHIKV, Ebola. Jamaica Observer. 2014 Nov 6: News.

16. Krishnamoorthy K, Harichandrakumar KT, Krishna Kumari A, Das LK. Burden of chikungunya in India: estimates of disability adjusted life years (DALY) lost in 2006 epidemic. J Vector Borne Dis 2009; 46: 26-35.

17. Vijayakumar K, George B, Anish TS, Rajasi RS, Teena MJ, Sujina CM. Economic impact of chikungunya epidemic: out-of-pocket health expenditures during the 2007 outbreak in Kerala, India. Southeast Asian J Trop Med Public Health 2013; 44: 54-61.

18. Gopalan SS, Das A. Household economic impact of an emerging disease in terms of catastrophic out-of-pocket health care expenditure and loss of productivity: investigation of an outbreak of chikungunya in Orissa, India. J Vector Borne Dis 2009; 46: 57-64.

19. Khan SA, Dutta P, Topno R, Borah J, Chowdhury P, Mahanta J. Chikungunya outbreak in Garo Hills, Meghalaya: An epidemiological perspective. Indian J Med Res 2015; 141: 591-7.

20. Wangchuk S, Chinnawirotpisan P, Dorji T, Tobgay T, Dorji T, Yoon I-K, Fernandez S. Chikungunya Fever Outbreak, Bhutan, 2012. Emerg Infect Dis 2013 ; 19: 1681-4.
21. Elenjickal MG, Sushamabai S. Outbreak of Chikungunya disease in Kerala in 2007. Indian Pediatr 2009; 46: 440-1.

22. Ramful D, Carbonnier M, Pasquet M, Bouhmani B, Ghazouani J, Noormahomed $\mathrm{T}$ et al. Mother-to-child transmission of Chikungunya virus infection. Pediatr Infect Dis J 2007; 26: 811-5.

23. Teo TH, Her Z, Tan JJ, Lum FM, Lee WW, Chan YH et al. Caribbean and La Réunion Chikungunya virus isolates differ in their capacity to induce proinflammatory Th1 and NK cell responses and acute joint pathology. J Virol 2015; 89: 7955-69.

24. Singh SS, Manimunda SP, Sugunan AP, Sahina, Vijayachari P. Four cases of acute flaccid paralysis associated with chikungunya virus infection. Epidemiol Infect 2008; 136: 1277-80.

25. Ganesan K, Diwan A, Shankar SK, Desai SB, Sainani GS, Katrak SM Chikungunya encephalomyeloradiculitis: report of 2 cases with neuroimaging and 1 case with autopsy findings. AJNR Am J Neuroradiol 2008; 29: 1636-7.

26. Mittal A, Mittal S, Bharati MJ, Ramakrishnan R, Saravanan S, Sathe PS. Optic neuritis associated with chikungunya virus infection in South India. Arch Ophthalmol 2007; 125: 1381-6.

27. Bhavana K, Tyagi I, Kapila RK. Chikungunya virus induced sudden sensorineural hearing loss. Int J Pediatr Otorhinolaryngol 2008; 72: 257-9.

28. Robin S, Ramful D, Le Seach F, Jaffar-Bandjee MC, Rigou G, Alessandri JL. Neurologic manifestations of pediatric chikungunya infection. J Child Neurol 2008; 23: 1028-35.

29. van Genderen FT, Krishnadath I, Sno R, Grunberg MG, Zijlmans W, Adhin MR. First Chikungunya outbreak in Suriname; clinical and epidemiological features. PLoS Negl Trop Dis 2016; 10: e0004625.

30. Wei Chiam C, Fun Chan Y, Chai Ong K, Thong Wong K, Sam IC. Neurovirulence comparison of chikungunya virus isolates of the Asian and East/Central/South African genotypes from Malaysia. J Gen Virol 2015; 96: 3243-54.

31. Davidson TD, Christie CDC. Outcome of Dengue in hospitalized Jamaican children. West Indian Med J 2016 Oct 26. doi:10.7727/ wimj.2016.525 [Epub ahead of print].

32. Webster-Kerr KR, Christie CDC, Grant A, Chin D, Burrowes H, Clarke $\mathrm{K}$ et al. Emergence of the ZIKA virus epidemic and the national response in Jamaica. In press, West Indian Med J 2016; 65; 1: 243-9

33. Weaver SC, Osorio JE, Livergood JA, Chen R, Stinchcomb D. Chikungunya virus and prospects for a vaccine. Expert Rev Vaccines 2012; 11: 1087-101.

34. Chang L, Dowd K, Mendoza FM, Saunders J, Sitar S, Plummer SH et al. Safety and tolerability of chinkungunya virus-like particle vaccine in health adults: a phase 1 dose-escalation trial. The Lancet 2014; $\mathbf{3 8 4}$ : 2046-52. 